\title{
Activation of innate and adaptive immunity as an effective combined strategy for cancer immunotherapy
}

\author{
Alexander Rakhmilevich ${ }^{1 *}$, Mildred Felder ${ }^{1}$, Lauren Lever ${ }^{1}$, Tyler Van De Voort ${ }^{1}$, Alan J Korman², Stephen D Gillies ${ }^{3}$, \\ Paul M Sondel ${ }^{4}$
}

From 30th Annual Meeting and Associated Programs of the Society for Immunotherapy of Cancer (SITC 2015) National Harbor, MD, USA. 4-8 November 2015

Immunotherapeutic approaches can demonstrate some antitumor benefit, but their efficacy is limited when they are used as a single modality. We asked if a combinatory approach activating both innate and adaptive immunity would improve cancer immunotherapy. We have previously shown that an agonistic anti-CD40 monoclonal antibody (anti-CD40) in combination with a toll-like receptor 9 agonist, $\mathrm{CpG}$, can activate macrophages in mice, leading to tumor cell killing. Separately, we have shown that a direct intratumoral injection of an immunocytokine (IC) consisting of anti-GD2 antibody linked to interleukin-2 can activate NK and T cells, resulting in antitumor effects. We hypothesize that activation of macrophages (with anti-CD40/CpG) and NK cells (with IC) will increase tumor destruction and presentation of tumor antigens, leading to $\mathrm{T}$ cell activation, which in turn could be further augmented by anti-CTLA-4 antibody, resulting in tumor eradication and prevention of tumor recurrence. Using the mouse GD2 ${ }^{+}$B78 melanoma model, we show that anti-CD40/CpG and IC/antiCTLA-4 synergistically induced regression of established subcutaneous tumors, resulting in the cure of $50 \%$ of mice and development of immunological memory against B78 as well as wild type B16 tumors. While the antitumor effect of anti-CD40/CpG was $\mathrm{T}$ cell independent, the antitumor effect of IC/anti-CTLA-4 required $\mathrm{T}$ cells. Anti-CD40/CpG treatment led to upregulation of $\mathrm{T}$ cell activation markers in draining lymph nodes. Finally, the combined treatment with anti-CD40/CpG and IC/anti-CTLA-4 was effective against B16 lung

'UW-Madison, Madison, WI, USA

Full list of author information is available at the end of the article metastases. We suggest that a combination of antiCD40/CpG and IC/anti-CTLA-4 should be tested as a clinically relevant novel treatment strategy.

\section{Authors' details}

'UW-Madison, Madison, WI, USA. ${ }^{2}$ Bristol-Myers Squibb Company, Redwood City, CA, USA. ${ }^{3}$ Provenance Biopharmaceuticals, Carlisle, MA, USA.

${ }^{4}$ Department of Human Oncology, Department of Pediatrics, University of Wisconsin-Madison, Madison, WI, USA.

Published: 4 November 2015

doi:10.1186/2051-1426-3-S2-P370

Cite this article as: Rakhmilevich et al:: Activation of innate and adaptive immunity as an effective combined strategy for cancer immunotherapy. Journal for ImmunoTherapy of Cancer 2015 3(Suppl 2):P370.
Submit your next manuscript to BioMed Central and take full advantage of:

- Convenient online submission

- Thorough peer review

- No space constraints or color figure charges

- Immediate publication on acceptance

- Inclusion in PubMed, CAS, Scopus and Google Scholar

- Research which is freely available for redistribution
() Biomed Central 